\title{
Anaemia and thrombocytopenia in patients with prostate cancer and bone metastases
}

\author{
Carsten Nieder*1,2, Ellinor Haukland ${ }^{1}$, Adam Pawinski and Astrid Dalhaug ${ }^{1}$
}

\begin{abstract}
Background: The purpose of this study was to determine the incidence, risk factors and prognostic impact of anaemia and thrombocytopenia in patients with bone metastases (BM) from prostate cancer.

Methods: Retrospective cohort study including 51 consecutive patients treated at a community hospital. Twenty-nine patients $(57 \%)$ received taxotere after diagnosis of BM.

Results: Haemoglobin $(\mathrm{Hb}) \leq 12.0 \mathrm{~g} / \mathrm{dL}$ at BM detection was associated with shorter overall survival. During follow-up, 25 patients (49\%) experienced episodes with $\mathrm{Hb}<10 \mathrm{~g} / \mathrm{dL}$ unrelated to side effects of cancer therapy. Fifteen patients required red blood cell transfusion. Median time from diagnosis of $\mathrm{BM}$ to $\mathrm{Hb}<10 \mathrm{~g} / \mathrm{dL}$ was 23 months. Median survival from $\mathrm{Hb}<10 \mathrm{~g} / \mathrm{dL}$ was 5.4 months. There was no factor predicting for $\mathrm{Hb}<10 \mathrm{~g} / \mathrm{dL}$. Five patients (10\%) developed thrombocyte $(\operatorname{Trc})$ count $<50 \times 10 \% / \mathrm{L}$. All of these had previously received blood transfusion. Median interval from $\mathrm{Hb}<$ $10 \mathrm{~g} / \mathrm{dL}$ to $\operatorname{Trc}<50 \times 10^{\%} / \mathrm{L}$ was 2.5 months. Survival after thrombocytopenia was short ( 3 weeks to 4 months).

Haematuria and subdural haematoma were among the causes of death.

Conclusions: We found high rates of significant bone marrow failure in treatment-refractory patients. Both $\mathrm{Hb}<10 \mathrm{~g} /$ $\mathrm{dL}$ and $\operatorname{Trc}<50 \times 10^{9} / \mathrm{L}$ predict for unfavourable survival.
\end{abstract}

\section{Background}

Bone metastasis is a common complication in patients with advanced stage prostate cancer and might even be found already at first clinical diagnosis $[1,2]$. Depending on the extent of spread, bone marrow function might become compromised, resulting in anaemia und thrombocytopenia [3,4]. Prognosis after onset of anaemia und thrombocytopenia is not well described in the literature. In addition, factors predicting for these complications are poorly understood. To study the incidence, outcome and risk factors for anaemia and thrombocytopenia in men with prostate cancer and skeletal metastases, a retrospective cohort study was performed.

\section{Methods}

A retrospective analysis, which included all patients with prostate cancer and bone metastases treated at the authors' institution during 2007 and 2008, was performed. The authors' institution is a community hospital

* Correspondence: cnied@hotmail.com

1 Department of Internal Medicine - Division of Oncology and Palliative Medicine, Nordland Hospital, Bodø, Norway

Full list of author information is available at the end of the article in rural Norway, which is the only oncology care provider and services the complete population of the county, i.e. approximately 236,000 inhabitants. Thus, the 51 consecutive patients included in this study represent an unselected population. Follow-up information was available in all patients. Temporary anaemia, leuko- and thrombocytopenia episodes might result from chemotherapy or radioisotope toxicity, necessitating for example chemotherapy dose reduction. Such toxicity is reversible and not expected to predict short survival. The present analysis did not include reversible events in patients who received chemotherapy or radioisotopes at the time of the event. It is focused on anaemia and thrombocytopenia resulting from disease progression. The cut-off for low $\mathrm{Hb}$ was set at $10.0 \mathrm{~g} / \mathrm{dL}$ as patients with higher values are not expected to receive red blood cell transfusion. Regarding Trc, $50 \times 10^{9} / \mathrm{L}$ was chosen as higher values will not result in bleeding complications. The normal range for haemoglobin $(\mathrm{Hb})$ was $13.4-17.0 \mathrm{~g} / \mathrm{dL}$. The normal range for thrombocytes $(\mathrm{Trc})$ was $130-400 \times 10^{9} / \mathrm{L}$. We used the Kaplan-Meier method to generate actuarial survival curves. Patients without event were censored at 
last clinical follow-up. Survival was calculated from the date of imaging diagnosis of bone metastases (typically by isotope bone scan) or from development of $\mathrm{Hb}<10 \mathrm{~g} / \mathrm{dL}$. Survival curves were compared with the log rank test. Wilcoxon- and Kruskal-Wallis-tests were used to compare the baseline characteristics between different groups. A p-value $\leq 0.05$ was considered statistically significant.

\section{Results}

The patient characteristics and length of follow-up are shown in Table 1. Treatment consisted of different types of androgen suppression regimens incl. steroids and palliative external beam radiotherapy in patients with bone pain, metastatic spinal cord compression or surgically stabilized pathological fractures. Administration of other treatments is also shown in Table 1 . Twenty-nine patients (57\%) received taxotere after diagnosis of bone metastases and 7 of these also proceeded to second-line treatment with mitoxantrone. The initial number of bone metastases on radioisotope bone scan was significantly higher in patients with synchronous presentation $(25 \%$ with up to 10 foci, $55 \%$ with more than 10 foci and $20 \%$ with super scan) compared to metachronous presentation (52\% with up to 10 foci, $45 \%$ with more than 10 foci and $3 \%$ with super scan), $\mathrm{p}=0.05$. Patients with synchronous presentation also had significantly higher median prostate-specific antigen (PSA) value, $\mathrm{p}<0.01$ (Table 1 ). No other significant differences in baseline characteristics were found between these two groups.

All baseline characteristics shown in Table 1 were examined for their prognostic impact. Patients with bone metastases at initial diagnosis had a 2-year survival rate of $61 \%$ versus $55 \%$ in those with metachronous bone metastases (Figure 1, p = 0.6). PSA level significantly influenced survival, but only in patients with metachronous bone metastases. The 2-year survival rate was $30 \%$ in patients with PSA $\geq 21 \mu \mathrm{g} / \mathrm{L}$ at the time of bone metastases detection versus $71 \%$ in those with lower PSA, p < 0.01 . While $\mathrm{Hb}$ at the time of bone metastases detection was not significant when using the median value as cutoff, a strong trend for correlation between $\mathrm{Hb} \leq 12.0 \mathrm{~g} / \mathrm{dL}$ and short survival was found, $\mathrm{p}=0.03$ (when correcting for the fact that 2 tests were performed, i.e. median $\mathrm{Hb}$ and $\mathrm{Hb} \leq 12.0 \mathrm{~g} / \mathrm{dL}$, the Bonferroni correction requires $\mathrm{p}$ $\leq 0.025$ ). Four of 5 patients with $\mathrm{Hb} \leq 12.0 \mathrm{~g} / \mathrm{dL}$ died within 18 months. None of the other factors significantly correlated with survival. Given these results, a multivariate analysis did not appear appropriate. Among the treatment-related factors, only the administration of chemotherapy significantly influenced survival. The 2year rate was $68 \%$ in chemotherapy-treated patients versus $41 \%$ in others, $\mathrm{p}=0.04$.
Overall, 25 patients (49\%) experienced episodes with $\mathrm{Hb}<10 \mathrm{~g} / \mathrm{dL}$ in the absence of chemotherapy and radioisotope injection, typically as a sign of disease progression indicating failure of the current treatment line. Fifteen of these patients (60\%) required red blood cell transfusion (29\% of all patients in the study). Erythropoiesis stimulating agents were not used. The median time from diagnosis of bone metastases to $\mathrm{Hb}<10 \mathrm{~g} / \mathrm{dL}$ was approximately 2 years (Figure 2). Median survival from $\mathrm{Hb}<10 \mathrm{~g} / \mathrm{dL}$ was 5.4 months (Figure 3 ). There was no factor predicting for episodes with $\mathrm{Hb}<10 \mathrm{~g} / \mathrm{dL}$. Interestingly, patients having had $\mathrm{Hb}$ below median at diagnosis of bone metastases were not at increased risk of developing $\mathrm{Hb}<10 \mathrm{~g} / \mathrm{dL}$ during the course of disease. Their risk was $43 \%$ as compared to $59 \%$ in patients with $\mathrm{Hb}$ above median. Figure 4 shows that patients who maintained $\mathrm{Hb} \geq 10 \mathrm{~g} / \mathrm{dL}$ during follow-up had significantly longer survival from first diagnosis of bone metastases as compared to patients who developed $\mathrm{Hb}<10 \mathrm{~g} /$ dL. Five patients $(10 \%)$ developed episodes with $\operatorname{Trc}<50$ $\times 10^{9} / \mathrm{L}$. All of these had previously experienced $\mathrm{Hb}<10$ $\mathrm{g} / \mathrm{dL}$ and received red blood cell transfusion. Thus, 5 of 15 patients (33\%) who had required transfusion also developed severe thrombocytopenia. The interval from $\mathrm{Hb}<10 \mathrm{~g} / \mathrm{dL}$ to $\operatorname{Trc}<50 \times 10^{9} / \mathrm{L}$ was $1-4$ months, median 2.5 months. The outcome of these 5 patients is shown in Table 2. In spite of repeat platelet transfusion survival was short, ranging from 3 weeks to 4 months. No bleeding episodes were registered in patients who never presented with $\operatorname{Trc}<50 \times 10^{9} / \mathrm{L}$. No patients developed severe leucocytopenia in the absence of chemotherapy administration or complications related to low white blood cell counts.

\section{Discussion}

The present study is to our best knowledge the only contemporary series examining the incidence, outcome and risk factors for development of anaemia and thrombocytopenia in patients treated for bone metastases from prostate cancer. To avoid confounding factors, reversible events caused by chemotherapy or radioisotope toxicity were not evaluated. Reversibility was determined by retrospective chart review. Beyond general limitations of retrospective studies, which might contain hidden sources of bias, one should be aware of the limited patient number and thus statistical power. We can not exclude the possibility that a larger study could have identified factors predicting for episodes with $\mathrm{Hb}<10 \mathrm{~g} / \mathrm{dL}$. However, the data are derived from a representative unselected patient population, actually including all men with bone metastases from prostate cancer in a well defined geographical region. Therefore, it is likely that our findings apply to many men with bone metastases from pros- 
Table 1: Baseline characteristics of 51 men with prostate cancer and bone metastases

\begin{tabular}{|c|c|c|c|}
\hline Parameter & All 51 patients & $\begin{array}{c}20 \text { patients with bone } \\
\text { metastases at first cancer } \\
\text { diagnosis }\end{array}$ & $\begin{array}{l}31 \text { patients with metachronous } \\
\text { diagnosis of bone metastases }\end{array}$ \\
\hline Median age, range (years)* & $67,56-86$ & $64.5,57-79$ & $73,56-86$ \\
\hline Median age at first cancer diagnosis & $66,53-80$ & $64.5,57-79$ & $68,53-80$ \\
\hline Median interval, range (months) & $18,0-159$ & 0 & $46,5-159$ \\
\hline Median PSA, range $(\mu \mathrm{g} / \mathrm{L})^{*}$ & $51,3.9-10,302$ & $339,42-10,302$ & $21,3.9-727$ \\
\hline Median $\mathrm{Hb}$, range $(\mathrm{g} / \mathrm{dL})^{*}$ & $13.6,10.2-16.8$ & $13.9,10.9-16.8$ & $13.4,10.2-15.2$ \\
\hline Median $\operatorname{Trc}$, range $\left(\times 10^{9} / \mathrm{L}\right)^{*}$ & $218,137-447$ & $295,137-435$ & $198,143-447$ \\
\hline Gleason score $<7,7,>7^{* *}$ & $\begin{array}{c}6,9,23 \\
16 \%, 24 \%, 61 \%\end{array}$ & $\begin{array}{c}2,4,9 \\
13 \%, 27 \%, 60 \%\end{array}$ & $\begin{array}{c}4,5,14 \\
17 \%, 22 \%, 61 \%\end{array}$ \\
\hline Other distant metastases & $\begin{array}{c}17 \\
33 \%\end{array}$ & $\begin{array}{c}6 \\
30 \%\end{array}$ & $\begin{array}{c}11 \\
35 \%\end{array}$ \\
\hline $\begin{array}{c}\leq 10 \text { bone metastases, }>10 \\
\text { superscan }\end{array}$ & $\begin{array}{c}21,25,5 \\
41 \%, 49 \%, 10 \%\end{array}$ & $\begin{array}{c}5,11,4 \\
20 \%, 55 \%, 20 \%\end{array}$ & $\begin{array}{c}16,14,1 \\
52 \%, 45 \%, 3 \%\end{array}$ \\
\hline $\begin{array}{l}\text { Initial prostatectomy or radical } \\
\text { radiotherapy }\end{array}$ & $\begin{array}{c}8 \\
16 \%\end{array}$ & 0 & $\begin{array}{c}8 \\
26 \%\end{array}$ \\
\hline Taxotere treatment & $\begin{array}{c}29 \\
57 \%\end{array}$ & $\begin{array}{c}12 \\
60 \%\end{array}$ & $\begin{array}{c}17 \\
55 \%\end{array}$ \\
\hline Zoledronic acid treatment & $\begin{array}{c}41 \\
80 \%\end{array}$ & $\begin{array}{c}17 \\
85 \%\end{array}$ & $\begin{array}{c}24 \\
77 \%\end{array}$ \\
\hline Radioisotope treatment & $\begin{array}{c}8 \\
16 \%\end{array}$ & $\begin{array}{c}5 \\
25 \%\end{array}$ & $\begin{array}{c}3 \\
10 \%\end{array}$ \\
\hline $\begin{array}{l}\text { Median follow-up of living patients, } \\
\text { range (months) }\end{array}$ & $26,9-84$ & $31,12-84$ & $22,9-67$ \\
\hline
\end{tabular}

tate cancer treated outside of clinical trials by practicing oncologists. We had to arbitrarily define anaemia and thrombocytopenia. Other cut-off values might have been possible, but we decided to consider the probability for red blood cell transfusion and risk of bleeding when choosing $\mathrm{Hb}<10 \mathrm{~g} / \mathrm{dL}$ and $\operatorname{Trc}<50 \times 10^{9} / \mathrm{L}$. All relevant clinical events were captured when applying these cut-off values. Geenen et al. have previously shown that the white blood cell system did not seem to be affected in patients with metastatic prostate cancer [5]. The present study confirms this result.

Treatment was individualised, taking into account age, organ function, performance status, symptoms etc. The majority of patients (57\%) received taxotere after diagno- 


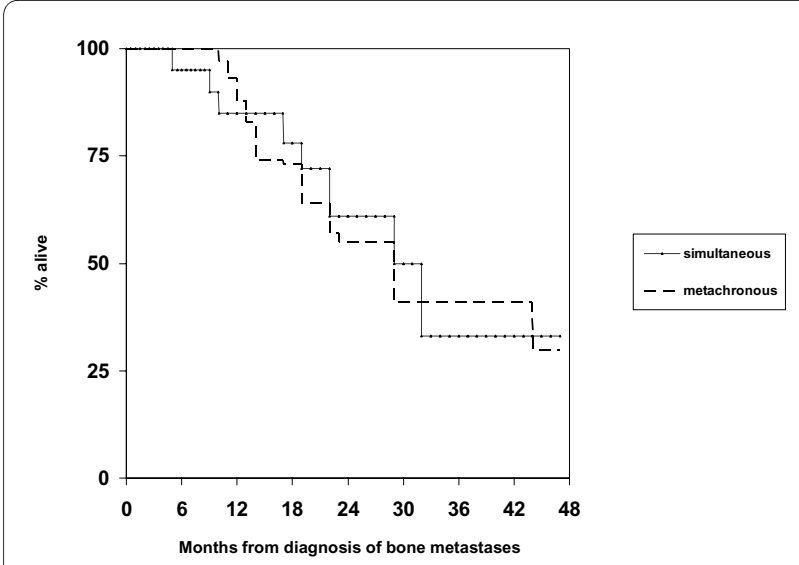

Figure 1 Kaplan-Meier estimates of overall survival in 20 patients with bone metastases from prostate cancer, which were present at first cancer diagnosis, versus 31 patients who developed metachronous bone metastases during the course of disease, $p=$ 0.6

sis of bone metastases and some patients also had second-line treatment with mitoxantrone. Administration of chemotherapy significantly influenced survival. The 2year rate was $68 \%$ in chemotherapy-treated patients versus $41 \%$ in others. This difference is only partially attributable to treatment as this was a retrospective study where several sources of bias influenced the choice of treatment. Survival in most patients was $2-3$ years, but 4

Table 2: Outcome in all 5 patients who developed thrombocyte (Trc) count $<50 \times 109 / \mathrm{L}$ after diagnosis of bone metastases

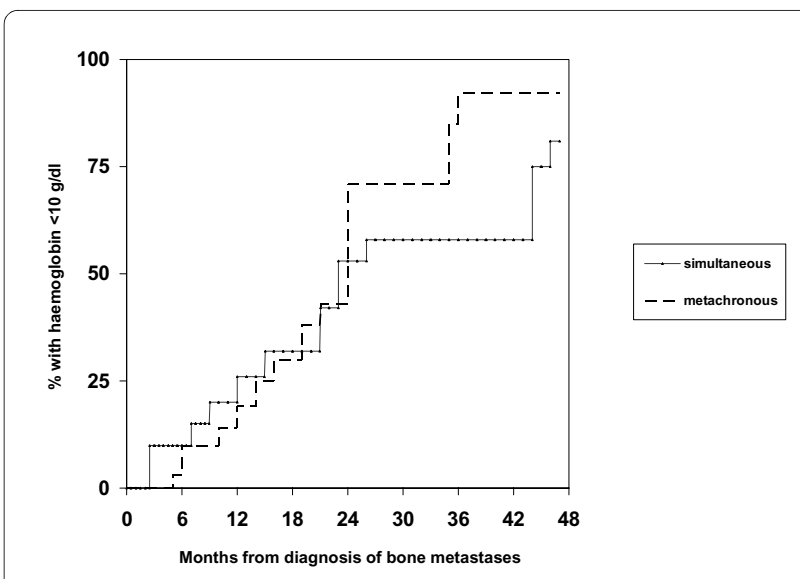

Figure 2 Kaplan-Meier estimates of time to haemoglobin $<10 \mathrm{~g} /$ $\mathrm{dL}$ in 20 patients with bone metastases from prostate cancer, which were present at first cancer diagnosis, versus 31 patients who developed metachronous bone metastases during the course of disease, $p=0.4$.

patients were alive more than 5 years after the detection of bone metastases.

It should also be noticed that androgen deprivation therapy might result in declining $\mathrm{Hb}$, e.g., mean reduction by $1.1 \mathrm{~g} / \mathrm{dL}$ in the study by Curtis et al. [6]. Beer et al. observed a mean decline of $0.54 \mathrm{~g} / \mathrm{dL} 3$ months after starting androgen deprivation therapy [7]. However, the mean level increased in patients with baseline level $<12$ $\mathrm{g} / \mathrm{dL}$. A decline after 3 months was associated indepen-

\begin{tabular}{|c|c|c|c|c|c|}
\hline Patient nr. & Presentation & $\begin{array}{l}\text { Minimum } \\
\text { Trc count }\end{array}$ & $\begin{array}{l}\text { Time from bone metastases } \\
\text { to } \operatorname{Trc}<50 \times 109 / \mathrm{L}\end{array}$ & $\begin{array}{c}\text { Previous systemic } \\
\text { therapy }\end{array}$ & $\begin{array}{l}\text { Outcome after } \\
\text { Trc }<50 \times 109 / \mathrm{L}\end{array}$ \\
\hline 1 & Synchronous & $15 \times 10^{9} / \mathrm{L}$ & 18 months & END, ZA, TAX, MITO & $\begin{array}{c}\text { Died after } 4 \text { weeks, cause } \\
\text { unknown }\end{array}$ \\
\hline 2 & Synchronous & $19 \times 10^{9} / \mathrm{L}$ & 16 months & END, ZA, TAX & $\begin{array}{c}\text { Died from haematuria and } \\
\text { kidney failure after } 8 \\
\text { weeks }\end{array}$ \\
\hline 3 & Synchronous & $20 \times 10^{9} / \mathrm{L}$ & 27 months & END, ZA, TAX & $\begin{array}{l}\text { Developed subdural } \\
\text { haematoma but died from } \\
\text { sepsis after } 4 \text { months }\end{array}$ \\
\hline 4 & Synchronous & $26 \times 10^{9} / \mathrm{L}$ & 4 months & END, ZA & $\begin{array}{c}\text { Died from surgery } \\
\text { complications (for pathol. } \\
\text { fracture) after } 3 \text { weeks }\end{array}$ \\
\hline 5 & Metachronous & $30 \times 10^{9} / \mathrm{L}$ & 9 months & END, ZA & $\begin{array}{c}\text { Died from subdural } \\
\text { haematoma after } 3 \text { weeks }\end{array}$ \\
\hline
\end{tabular}




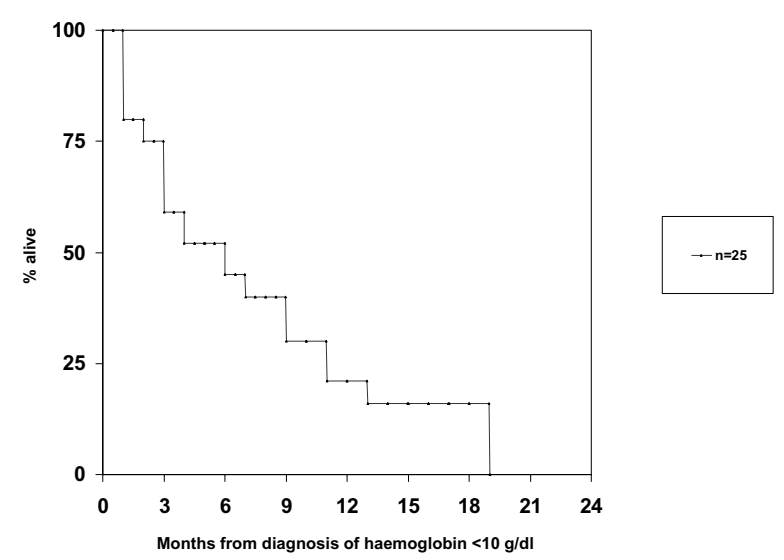

Figure 3 Kaplan-Meier estimate of overall survival after detection of haemoglobin $<10 \mathrm{~g} / \mathrm{dL}$ in 25 patients.

dently with shorter survival and progression-free survival. Already in a previous study, the same group had described an association between anaemia and shorter survival in men with newly diagnosed metastatic prostate cancer [8]. These recent results confirm established prognostic models such as the one developed by Halabi et al., which includes, e.g., $\mathrm{Hb}$, alkaline phosphatase, lactate dehydrogenase and PSA [9]. Because the focus of the present study was on haematological events, detailed analyses of all prognostic factors for survival including alkaline phosphatase and lactate dehydrogenase were not performed. Other authors demonstrated that patients with lower $\mathrm{Hb}$ had more advanced disease on bone scan [10]. The time to development of bone metastases (synchronous versus metachronous presentation) and the number of foci on isotope bone scan had no influence on any outcome in the present study. The same holds true

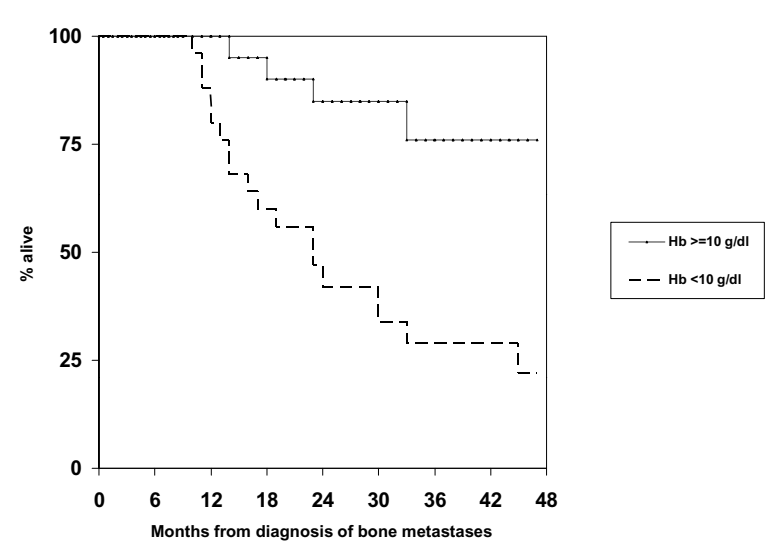

Figure 4 Kaplan-Meier estimates of overall survival from first diagnosis of bone metastases in 25 patients who developed haemoglobin $<10 \mathrm{~g} / \mathrm{dL}$ during follow-up versus 26 patients who maintained higher haemoglobin levels, $p=0.01$. for age and distant metastases at non-skeletal sites. While $\mathrm{Hb}$ at the time of bone metastases detection was not significant when using the median value as cut-off, an association of $\mathrm{Hb} \leq 12.0 \mathrm{~g} / \mathrm{dL}$ and short survival might be present.

A large number of patients (49\%) experienced episodes with $\mathrm{Hb}<10 \mathrm{~g} / \mathrm{dL}$ unexplained by chemotherapy and radioisotope toxicity, but reflecting disease progression. Sixty percent of patients with $\mathrm{Hb}<10 \mathrm{~g} / \mathrm{dL}$ required red blood cell transfusion (29\% of all patients in the study). In a previous study, only $10 \%$ of patients became anaemic and $7.5 \%$ received red blood cell transfusion, but that study was limited to the final year of life and largely to the pre-taxotere era [4]. Notably the decision to transfuse and timing is somewhat subjective and varies from physician to physician. It should also be noted that we did not administer erythropoiesis stimulating agents, which might reduce the need for transfusion, given the debate around these agents and recent recommendations [1113]. Median survival from $\mathrm{Hb}<10 \mathrm{~g} / \mathrm{dL}$ was 5.4 months. Thus, this factor predicts when the disease reaches a critical point where the remaining life time is very limited. No risk factors for development of $\mathrm{Hb}<10 \mathrm{~g} / \mathrm{dL}$ could be identified. Five patients (10\%) developed episodes with $\operatorname{Trc}<50 \times 10^{9} / \mathrm{L}$. All of these had previously experienced $\mathrm{Hb}<10 \mathrm{~g} / \mathrm{dL}$ and received red blood cell transfusion. Thus, 5 of 15 patients (33\%) who had required transfusion also developed severe thrombocytopenia. Survival after detection of severe thrombocytopenia was short, ranging from 3 weeks to 4 months. Complications such as haematuria, subdural haematoma and the inability to recover from emergency surgery were among the causes of death.

\section{Conclusions}

Declining bone marrow function continues to be a common event during the course of prostate cancer with skeletal metastases. It contributes significantly to morbidity and mortality and poses challenges to those involved in palliative care for these patients. The current survival figures after detection of $\mathrm{Hb}<10 \mathrm{~g} / \mathrm{dL}$ and $\operatorname{Trc}<50 \times 10^{9} / \mathrm{L}$ should be regarded as initial estimates, which need to be confirmed in larger studies.

\section{Competing interests}

The authors declare that they have no competing interests.

\section{Authors' contributions}

$\mathrm{CN}, \mathrm{EH}$ and $\mathrm{AD}$ participated in the design of the study, EH, AD and AP collected patient data and follow-up information, CN carried out the statistical analysis, $\mathrm{CN}$ and AP drafted the manuscript. All authors read and approved the final manuscript.

\section{Acknowledgements}

None. Sources of funding: none. 


\section{Author Details}

'Department of Internal Medicine - Division of Oncology and Palliative Medicine, Nordland Hospital, Bodø, Norway and IInstitute of Clinical Medicine, Faculty of Medicine, University of Troms $\varnothing$, Troms $\varnothing$, Norway

Received: 19 November 2009 Accepted: 13 June 2010

Published: 13 June 2010

\section{References}

1. Hernes E, Kyrdalen A, Kvåle R, Hem E, Klepp O, Acrona K, Fosså SD: Initial management of prostate cancer: first year experience with the Norwegian National Prostate Cancer Registry. BJU Int 2009, 105:805-11.

2. Meulenbeld HJ, Hamberg P, de Wit R: Chemotherapy in patients with castration-resistant prostate cancer. Eur J Cancer 2009, 45(Suppl 1):161-171.

3. Nalesnik JG, Mysliwiec AG, Canby-Hagino E: Anemia in men with advanced prostate cancer: incidence, etiology, and treatment. Rev Urol 2004, 6:1-4

4. Khafagy R, Shackley D, Samuel J, O'Flynn K, Betts C, Clarke N: Complications arising fin the final year of life in men dying from advanced prostate cancer. J Palliat Med 2007, 10:705-711.

5. Geenen RW, Delaere KP, van Wersch JW: Haematological variables in prostatic carcinoma patients. Acta Urol Belg 1996, 64:21-26.

6. Curtis KK, Adam TJ, Chen SC, Pruthi RK, Gornet MK: Anaemia following initiation of androgen deprivation therapy for metastatic prostate cancer: a retrospective chart review. Aging Male 2008, 11:157-161.

7. Beer TM, Tangen CM, Bland LB, Hussain M, Goldman BH, DeLoughery TG, Crwaford ED, Southwest Oncology Group: The prognostic value of hemoglobin change after initiating androgen-deprivation therapy for newly diagnosed metastatic prostate cancer: A multivariate analysis of Southwest Oncology Group Study 8894. Cancer 2006, 107:489-496.

8. Beer TM, Tangen CM, Bland LB, Thompson IM, Crawford ED: Prognostic value of anemia in newly diagnosed metastatic prostate cancer: a multivariate analysis of Southwest Oncology Group Study 8894. J Urol 2004 172:2213-2217. Erratum in 174: 1156

9. Halabi S, Small EJ, Kantoff PW, Kattan MW, Kaplan EB, Dawson NA, Levine EG, Blumenstein BA, Vogelzang NJ: Prognostic model for predicting survival in men with hormone-refractory metastatic prostate cancer. $J$ Clin Oncol 2003, 21:1232-1237.

10. Nakashima J, Kikuchi E, Miyajima A, Nakagawa K, Oya M, Ohigashi T, Murai M: Simple stratification of survival using bone scan and serum Creactive protein in prostate cancer patients with metastases. Urol Int 2008, 80:129-133.

11. Bohlius J, Schmidlin K, Brillant C, Schwarzer G, Trelle S, Seidenfeld J, Zwahlen M, Clarke M, Weingart O, Kluge S, Piper M, Rades D, Steensma DP, Djulbegovic B, Fey MF, Ray-Coquard I, Machtay M, Moebus V, Thomas G, Untch M, Schumacher M, Egger M, Engert A: Recombinant human erythropoiesis-stimulating agents and mortality in patients with cancer: a meta-analysis of randomised trials. Lancet 2009, 373:1532-1542.

12. Rizzo JD, Somerfield MR, Hagerty KL, Seidenfeld J, Bohlius J, Bennett $C L$, Cella DF, Djulbegovic B, Goode MJ, Jakubowski AA, Rarick MU, Regan DH, Lichtin AE, American Society of Clinical Oncology; American Society of Hematology: Use of epoetin and darbepoetin in patients with cancer: 2007 American Society of Clinical Oncology/American Society of Hematology clinical practice update. J Clin Oncol 2008, 26:132-149.

13. Greil R, Thödtman R, Roila F, ESMO Guidelines Working Group: Erythropoietins in cancer patients: ESMO recommendations for use. Ann Oncol 2008, 19(Suppl 2):ii113-15.

\section{Pre-publication history}

The pre-publication history for this paper can be accessed here: http://www.biomedcentral.com/1471-2407/10/284/prepub

doi: 10.1186/1471-2407-10-284

Cite this article as: Nieder et al., Anaemia and thrombocytopenia in patients with prostate cancer and bone metastases BMC Cancer 2010, 10:284

\section{Submit your next manuscript to BioMed Centra} and take full advantage of:

- Convenient online submission

- Thorough peer review

- No space constraints or color figure charges

- Immediate publication on acceptance

- Inclusion in PubMed, CAS, Scopus and Google Scholar

- Research which is freely available for redistribution 